\title{
Pengaruh Iklan BTS Selalu Ada Selalu Bisa terhadap Minat Pemakaian Aplikasi Tokopedia pada Mahasiswa Universitas Tarumanagara
}

\author{
Ellen $^{1}$, Moehammad Gafar Yoedtadi ${ }^{2 *}$ \\ ${ }^{1}$ Fakultas Ilmu Komunikasi, Universitas Tarumanagara, Jakarta \\ Email: ellen.915180219@stu.untar.ac.id \\ ${ }^{2}$ Fakultas Ilmu Komunikasi, Universitas Tarumanagara, Jakarta* \\ Email: gafary@fikom.untar.ac.id
}

Masuk tanggal : 15-12-2021 revisi tanggal :06-01-2022, diterima untuk diterbitkan tanggal : 16-01-2022

\begin{abstract}
The development of communication in today's digital era gives the impact that brings many changes in human life. Especially on e-commerce Tokopedia, in increasing its appeal to increase the usage of the app, in cooperation with the idol group from South Korea named BTS. Idol group K-Pop BTS is increasingly accepted by young teenagers, of course, have an achievement and its popularity is currently rising. In the study has two variables, the variable influence of advertising and the variables of interest in the use of the application with the approach of the research is quantitative and the method of a survey of 100 respondents and the questionnaire is the instrument of the author. The respondent's data processing was tested to be valid, reliable and normal. The data analysis technique used is simple linear regression test and $T$ test. The results of the research analysis show that the advertising influence variable has an influence on the interest variable in using the application. This statement is strengthened based on the results of the $T$ test, that the effect of advertising (X) has a significant influence on the interest in using the application $(Y)$ so that $\mathrm{HO}$ is rejected and $\mathrm{HI}$ is accepted.
\end{abstract}

Keywords: advertising, BTS, hypodermic needles, interest in using applications, Tokopedia

\begin{abstract}
Abstrak
Perkembangan komunikasi pada era digital saat ini memberikan dampak yang membawa banyak perubahan dalam kehidupan manusia. Terutama pada e-commerce Tokopedia, dalam meningkatkan daya tariknya untuk meningkatkan pemakaian aplikasi, dengan menggandeng idol group dari Korea Selatan bernama BTS. Grup idola K-Pop BTS yang semakin diterima oleh remaja muda, tentunya memiliki sebuah prestasi dan popularitasnya yang saat ini semakin naik. Dalam penelitian memiliki dua variabel yaitu, variabel pengaruh iklan dan variabel minat pemakaian aplikasi dengan pendekatan penelitian yakni kuantitatif serta metode survei terhadap 100 responden dan kuesioner yang merupakan instrumen penulis. Pengolahan data responden teruji valid, reliabel dan normal. Teknik yang membantu peneliti dalam menganalisis data yakni uji regresi linear sederhana dan uji T. Hasil analisis penelitian menunjukkan pada variabel pengaruh iklan mempunyai pengaruh terhadap variabel minat pemakaian aplikasi. Pernyataan tersebut diperkuat berdasarkan hasil uji T, bahwa pengaruh iklan $(X)$ memiliki pengaruh yang cukup signifikan terhadap minat pemakaian aplikasi $(Y)$ sehingga HO ditolak dan H1 diterima.
\end{abstract}

Kata Kunci: BTS, iklan, jarum hipodermik, minat pemakaian aplikasi, Tokopedia 


\section{Pendahuluan}

Perkembangan komunikasi pada era digital saat ini tentunya memberikan sebuah dampak yang membawa banyak perubahan untuk berbagai aspek dalam kehidupan manusia. Terutama pada salah satu e-commerce yang dilakukan oleh Tokopedia, dalam menarik perhatian dalam meningkatkan minat pemakaian aplikasi Tokopedia pada tahun 2019-sekarang, dengan menggandeng idol group dari Korea Selatan bernama BTS. Budaya dan seni pada masa ini sering disebut K-pop, khususnya musik korea yang kini tengah digandrungi oleh remaja dewasa yaitu mahasiswa Universitas Tarumanagara (Untar). Grup idola K-Pop BTS yang semakin diterima oleh remaja muda, tentunya memiliki sebuah prestasi dan popularitasnya yang saat ini semakin naik. Hasil sensus dari good stats menyatakan fans BTS di Indonesia pada tahun 2020 menunjukkan sebanyak 80.895 fans.

Dari hal tersebut yang dimiliki oleh BTS, menarik perhatian Tokopedia serta melihat adanya peluang K-Pop untuk menjadi pusat perhatian pengguna aplikasi Tokopedia. Kemudian, Tokopedia melalui iklan yang berkampanye selalu ada selalu bisa berkolaborasi dengan BTS tersebut, berdampak pada perluasan iklan mengenai penggunaan aplikasi Tokopedia. Melalui kolaborasi ini, Tokopedia berharap dapat melakukan suatu upaya yang terbaik setiap hari bersama Tokopedia. Apabila pemanfaatan iklan yang berkolaborasi dengan idol group yakni BTS telah dianggap tepat dalam menjangkau pasarnya. Dilansir dari program talkshow di Korea Selatan yang berjudul "Rumor Has I $t$ " yang mengundang salah satu reporter yang bernama Choi Jeong Ah yang menyatakan bahwa untuk menjadikan BTS sebagai brand ambassador sekitar empat milyar won atau sekitar lima puluh milyar untuk mengajak kerja sama. Maka dari itu, penelitian ini bertujuan untuk mengetahui pengaruh iklan BTS selalu ada selalu bisa terhadap minat pemakaian aplikasi Tokopedia pada Mahasiswa Universitas Tarumanagara.

Komunikasi pemasaran sendiri bertujuan untuk memberikan informasi, mengajak khlayak, dan membantu untuk memberikan gambaran produk perusahaan dalam meningkatkan pemakaian produk yang telah diberikan oleh perusahaan untuk membangun sebuah hubungan. Komunikasi ini juga merupakan pertukaran informasi dua arah antara pihak atau lembaga-lembaga yang terlibat dalam pemasaran (Firmansyah, 2020) dengan buku yang berjudul "Komunikasi Pemasaran".

Sedangkan, menurut Warren J. Keagan (dalam Firmansyah, 2020), yang menginterpretasikan bahwa komunikasi pemasaran merupakan komponen yang menyampaikan sebuah arti dan juga hubungan kepada konsumen di perusahaan. Tujuannya untuk menginformasikan, menciptakan kesadaran jasa, kebutuhan dalam menggunakan produk dan hasrat sebuah jasa produk.

Perikanan adalah sekumpulan biaya yang ditanggung oleh sponsor untuk melakukan presentasi dan promosi nonpersonal berupa ide barang atau jasa (Kotler dan Armstrong dalam Siregar, 2016). Periklanan juga dapat dianggap sebagai pesan penjualan yang paling persuasif yang dikirimkan kepada pembeli paling potensial dari barang atau jasa tertentu dengan biaya serendah mungkin (Jefkins dalam Muchliat, 2011). Secara sederhana iklan didefinisikan sebagai pesan yang membawa produk kepada khalayak melalui suatu media. Sedangkan, menurut Barden dan Ingram at Wijaya et al. (2012) periklanan adalah unsur yang menggunakan bentuk komunikasi pemasaran atau nonpersonal dan disponsori oleh sponsor yang didistribusikan melalui meda massa yang tujuannya adalah mempromosikan penggunaan barang dan jasa.

Persaingan yang semakin ketat bagi perusahaan periklanan di sektor jasa on- 
line menuntut Tokopedia untuk mengembangkan ide-ide menarik untuk periklanan Youtube. Fungsinya dapat membangkitkan minat dan juga mempengaruhi kesadaran merek untuk menaklukkan pasar dengan nilai atau karakteristik yang membedakannya dari persaingan. Oleh karena itu, dibulan Maret 2021 Tokopedia menyelenggarakan advertensi Youtube berdurasi 16 detik dengan kampanye selalu ada selalu bisa yang berkolaborasi dengan salah satu idol group yang berasal dari agency BigHit Entertainment yakni Bangtan Boys atau yang sering disebut sebagai BTS merupakan boyband Korea yang memulai debut dibulan Juni 2013 serta beranggotakan ketujuh laki-laki yakni Ram Monster (RM), SUGA, Jin, J-Hope, V, Jimin, dan Jungkook.

Menurut Sumadiria (dalam Ratnawati, 2017), pada teori jarum hipodermik juga berkonsep bahwa "komunikasi satu arah yang berdasarkan anggapan bahwa media massa memiliki pengaruh langsung dan sangat menentukan terhadap khalayak komunikan (audience). Media massa merupakan gambaran dari jarum raksasa yang menyuntik khalayak komunikan yang pasif."

Minat pakai aplikasi menurut Jogiyanto (dalam Amaliah, 2018) adalah penggunaan dalam instruksi (instruction) atau pernyataan (statement) yang disusun sedemikian sehingga aplikasi dibuat untuk melayani kebutuhan akan beberapa aktivitas.

Dengan demikian, hipotesis dalam penelitian ini adalah:

- H0: tidak ada pengaruh antara pengaruh iklan BTS "Selalu Ada Selalu Bisa" terhadap minat pemakaian aplikasi Tokopedia pada mahasiswa Universitas Tarumanagara.

- H1: berpengaruh antara pengaruh iklan BTS "Selalu Ada Selalu Bisa” terhadap minat pemakaian aplikasi Tokopedia pada mahasiswa Universitas Tarumanagara.

\section{Metode Penelitian}

Metode penelitian kuantitatif adalah proses penemuan pengetahuan yang menggunakan data berupa angka sebagai alat untuk menganalisis informasi tentang apa yang ingin diketahui dari buku Methodology for Qualitative and Quantitative Research (Kasiram, 2008). Survei adalah cara menggunakan kuesioner sebagai alat pengumpulan data, tetapi tujuannya adalah untuk mendapatkan informasi dari berbagai responden yang diyakini dapat mewakili populasi tertentu (Kriyantono, 2020). Dalam jurnal ini peneliti menggunakan teknik bantuan dalam menganalisis data yang akan digunakan pada penelitian, sebagai berikut:

1) Uji Validitas

2) Uji Reliabilitas

3) Uji Normalitas

4) Uji Hipotesis (Uji T)

5) Analisis Regresi Liniear Sederhana

Penelitian ini bertujuan untuk mengetahui atau mengukur pengaruh iklan BTS selalu ada selalu bisa terhadap minat pemakaian aplikasi Tokopedia pada Mahasiswa Untar.

Tabel 1. Operasional Variabel

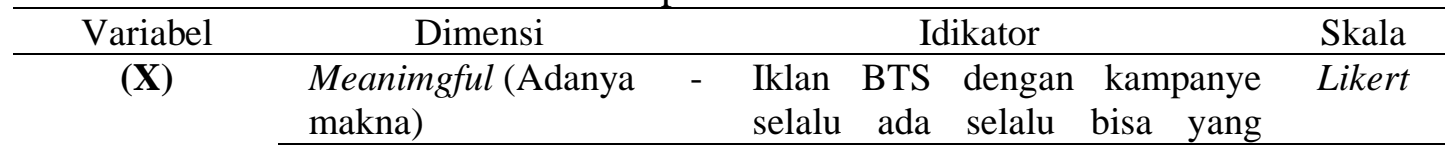




\begin{tabular}{|c|c|c|c|}
\hline \multirow[t]{3}{*}{$\begin{array}{l}\text { Pengaruh } \\
\text { Iklan } \\
\text { Kotler dan } \\
\text { Armstrong } \\
\text { (Siregar, } \\
\text { 2016) }\end{array}$} & & $\begin{array}{l}\text { ditampilkan oleh Tokopedia di } \\
\text { Youtube dapat mudah dimengerti } \\
\text { oleh khalayak. } \\
\text { - Iklan BTS dengan kampanye } \\
\text { selalu ada selalu bisa yang } \\
\text { ditampilkan oleh Tokopedia yang } \\
\text { dibutuhkan adalah sebuah } \\
\text { informasi yang berhubungan } \\
\text { dengan kebutuhan. }\end{array}$ & \\
\hline & $\begin{array}{l}\text { Believable (Dapat } \\
\text { dipercaya) }\end{array}$ & $\begin{array}{l}\text { Konten yang disampaikan oleh } \\
\text { BTS dalam menyampaikan } \\
\text { sebuah pesan di Youtube } \\
\text { Tokopedia, mengandung sebuah } \\
\text { informasi yang jelas yakni } \\
\text { realistis pada aplikasi, seperti } \\
\text { kualitas }\end{array}$ & Likert \\
\hline & $\begin{array}{l}\text { Distinctive (Adanya } \\
\text { keunggulan) }\end{array}$ & 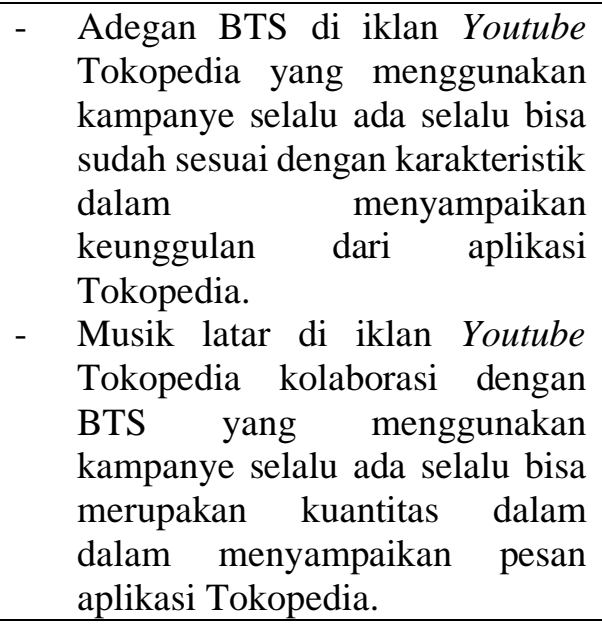 & Likert \\
\hline \multirow{4}{*}{$\begin{array}{c}\text { (Y) } \\
\text { Minat } \\
\text { Pemakaian } \\
\text { Aplikasi } \\
\text { Tokopedia } \\
\text { Kotler dan } \\
\text { Keller } \\
\text { (Siregar, } \\
\text { 2016) }\end{array}$} & Attetion (Perhatian) & $\begin{array}{l}\text { - Khalayak memperhatikan adanya } \\
\text { keunggulan yang ditampilkan } \\
\text { pada iklan Tokopedia yang } \\
\text { berkolaborasi dengan BTS yang } \\
\text { menggunakan kampanye selalu } \\
\text { ada selalu bisa. }\end{array}$ & Likert \\
\hline & Interest (Ketertarikan) & $\begin{array}{l}\text { - Khalayak merasa tertarik dengan } \\
\text { fitur yang ditampilkan pada iklan } \\
\text { Tokopedia yang berkolaborasi } \\
\text { dengan BTS. }\end{array}$ & Likert \\
\hline & Desire (Berniat) & $\begin{array}{ll}\text { Khalayak berniat menggunakan } \\
\text { aplikasi Tokopedia karena } \\
\text { tertarik dengan iklan Tokopedia } \\
\text { yang berkolaborasi dengan BTS }\end{array}$ & Likert \\
\hline & Action (Tindakan) & $\begin{array}{llr}\text { Khalayak menjadi pengguna } \\
\text { aplikasi Tokopedia karena } \\
\text { menganggap kualitasnya yang } \\
\text { lebih baik, sesuai dengan yang } \\
\text { diiklankan dan seara tidak }\end{array}$ & Likert \\
\hline
\end{tabular}


Ellen, Moehammad Gafar Yoedtadi: Pengaruh Iklan BTS Selalu Ada Selalu Bisa terhadap Minat Pemakaian Aplikasi Tokopedia pada Mahasiswa Universitas Tarumanagara

\begin{tabular}{lll}
\hline & langsung merasa nyaman saat & \\
& menggunakan aplikasinya. & \\
\hline Satisfaction & Khalayak memilik rasa kepuasan & Likert \\
(Kepuasan) & saat menggunakan aplikasi & \\
& Tokopedia. & \\
\end{tabular}

Sumber: Dokumentasi Pribadi

\section{Hasil Temuan dan Diskusi}

\section{Hasil Uji Validitas}

Tabel 2. Hasil Analisis Validitas

\begin{tabular}{cccc}
\hline No. Item & r hitung $(\mathrm{X})$ & $\mathrm{r}$ tabel $(\mathrm{Y})$ & Keterangan \\
\hline 1 & 0,843 & 0,722 & Valid \\
\hline 2 & 0,728 & 0,797 & Valid \\
\hline 3 & 0.768 & 0,753 & Valid \\
\hline 4 & 0,637 & 0,830 & Valid \\
\hline 5 & 0.783 & 0,713 & Valid \\
\hline
\end{tabular}

Sumber: Hasil Pengolahan Data Dengan SPSS 25

Tabel diatas menunjukkan sebuah hasil pada pernyataan dari variabel pengaruh iklan (X) dan variabel minat pemakaian aplikasi Tokkopedia (Y) dinyatakan absah (valid). Kemudian, untuk instrumen pernytaan bernilai (valid) jika nilai r-hitung lebih $>$ dari r-tabel dan nilai signifikansi < dari 0,05 r-tabel untuk 100 responden DF-2 $=$ $(100-2)=98$ sebesar 0.1966

\section{Hasil Uji Reliabilitas}

Penggunaan pengaruh iklan (X) yang memiliki nilai $r$ alpha sebesar 0,802 . Sedangkan, $r$ tabel sebesar 0,600 . Oleh karena itu $r$ alpha $>r$ tabel. Sehingga survei untuk variabel pengaruh iklan (X) tersebut bersifat reliabel atau konsisten. Kemudian, reliabilitas untuk variabel minat pemakaian aplikasi Tokopedia (Y) memiliki nilai $r$ alpha sebesar 0,818. Sedangkan, $r$ tabel sebesar 0,600. Oleh karena itu $\mathrm{r}$ alpha $>\mathrm{r}$ tabel. Sehingga survei untuk variabel minat pemakaian aplikasi Tokopedia (Y) tersebut bersifat reliabel atau konsisten.

\section{Hasil Uji Normalitas}

Metode yang digunakan yaitu uji normalitas dengan Kolmogorov-Smirnov. Kriteria pada pengujian ini taraf nyatanya 0,05 yang artinya jika probabilitas signifikansi data > 0,05. Diketahui bahwa nilai Statistic Kolomogorov-Smirnov dari keseluruhan variabel pada penelitian ini adalah 0,117. Maka hasilnya dapat dinyatakan atau disimpulkan $0,117>0,05$ bahwa data keseluruhan variabel bersifat normal.

\section{Hasil Uji Regresi Linier Sederhana}

Hasil pada penelitian ini adalah:

$$
\mathrm{Y}=4,730+0,764 \mathrm{X}
$$

Nilai 4,730 menandakan bahwa minat pemakaian aplikasi Tokopedia (Y) akan tetap konstanta sebesar positif 4,730 artinya apabila pengaruh iklan (X) bernilai 
nol (0) atau tidak mengalami perubahan naik ataupun turun yang biasa sering dikatakan nilainya tetap (konstan), maka variabel Y memiliki nilai sebesar 4,730.

Lalu, Koefisien regresi pengaruh iklan (X) sebesar 0,764 maksudnya adalah kenaikan 1 satuan pada variabel $\mathrm{X}$ akan mengakiatkan kenaikan variabel $\mathrm{Y}$ seesar 0,764. Lalu, untuk koefisiennya bersifat positif artinya arah hubungan antara variabel $\mathrm{X}$ dan variabel $\mathrm{Y}$ searah, jika variabel $\mathrm{X}$ meningkat maka variabel $\mathrm{Y}$ meningkat.

\section{Uji T}

Hasil uji T menyatakan, bahwa pengaruh iklan (X) terhadap minat pemakaian aplikasi Tokopedia (Y) dan signifikan (Sig) sebesar 0,000 < 0,05 sedangkan untuk nilai t hitung sebesar 16,430 > t tabel (1.98447). Dengan begitu hasil penelitian ini menggunakan hasil Uji $\mathrm{T}$ adalah $\mathrm{H} 0$ ditolak dan $\mathrm{H} 1$ diterima, yang berarti adanya pengaruh iklan $(\mathrm{X})$ dalam minat pemakaian aplikasi Tokopedia (Y).

\section{Simpulan}

Hasil penelitian menyatakan bahwa terdapat pengaruh iklan BTS selalu ada selalu bisa terhadap minat pemakaian aplikasi Tokopedia pada Mahasiswa Universitas Tarumanagara. Mayoritas responden merasa lebih percaya dengan iklan yang ditampilkan oleh Tokopedia, serta dapat beranggapan bahwa iklan yang telah ditampilkan tersebut cocok dan memiliki kesesuaian konsep dalam menyampaikan sebuah pesan kepada khalayak.

Berdasarkan hasil uji $\mathrm{T}$, $\mathrm{t}$ hitung $>\mathrm{t}$ tabel sehingga hipotesa pada pernyataan penelitian diterima dengan hasil yang telah diuraikan, yakni H0 ditolak dan H1 diterima. Yang artinya, bahwa pengaruh iklan BTS selalu ada selalu bisa tersebut mempengaruhi minat pemakaian aplikasi Tokopedia pada Mahasiswa Universitas Tarumanagara yang dikategorikan remaja.

Pengaruh iklan BTS dengan kampanye selalu ada selalu bisa terhadap minat pemakaian aplikasi Tokopedia pada Mahasiswa Universitas Tarumanagara, lebih cenderung perempuan karena lebih tertarik dengan menampilkan mega bintang yang popularitasnya cukup naik daun untuk mempromosikan jasa produk yang telah ditampilkan oleh perusahaan yakni Tokopedia.

\section{Ucapan Terima Kasih}

Penulis mengucapkan terima kasih kepada Fakultas Ilmu Komunikasi Universitas Tarumanagara, Tokopedia sebagai tempat penelitian, dan responden atas dukungan dan bantuannya kepada penulis dalam menyelesaikan penelitian ini.

\section{Daftar Pustaka}

Firmansyah, M. A. (2020). Komunikasi Pemasaran. Penerbit: Qiara Media. Good News Indonesia (2021, September 23). Indonesia Menjadi Negara Dengan Basis Penggemar BTS Terbanyak di Dunia. Diakses dari https://www.goodnewsfromindonesia.id/infographic/indonesia-menjadinegara-dengan-basis-penggemar-bts-terbanyak-di-dunia

Kasiram, M. (2010). Metodologi Penelitian: Kualitatif-Kuantitatif. Yogyakarta: UINMaliki Press. 
Kriyantono, R. (2020). Teknik praktis riset komunikasi kuantitatif dan kualitatif disertai contoh praktis Skripsi, Tesis, dan Disertai Riset Media, Public Relations, Advertising, Komunikasi Organisasi, Komunikasi Pemasaran. Rawamangun: Prenadamedia Group.

Muchliat, Y. P. (2011). Studi Observasi Konten Iklan Berdasarkan Tahapan Keputusan Pesan (Kasus Pada Majalah Gogirl)(Doctoral dissertation, $U A J Y)$.

Ratnawati, R. (2017). Strategi Kampanye Public Relations dalam Meningkatkan Kesadaran Masyarakat Melakukan Donor Darah pada Palang Merah Indonesia (PMI) Kota Makassar (Doctoral dissertation, Universitas Islam Negeri Alauddin Makassar).

Siregar, F. F. J. (2016). Pengaruh Periklanan (Advertising) dan Pemasaran Langsung (Direct Marketing) Terhadap Keputusan Pembelian Smartphone Samsung pada Mahasiswa Fakultas Ekonomi Program Studi Manajemen Universitas Medan Area.

Tokopedia (2019, Oktober 7). Tokopedia Umumkan BTS Sebagai Brand Ambassador. diambil kembali dari tokopedia.com: https://www.tokopedia.com/blog/tokopedia-announces-bts-as-the-companysbrand-ambassador/

Wijaya, N., \& Utami, L. S. S. (2012). Pengaruh Penyampaian Informasi pada Aplikasi TikTok terhadap Perilaku Konsumtif Generasi Z. Prologia, 5(2), 267-276. 